\title{
An Enactment Theory Model of Supplier Financial Disruption Risk Mitigation
}

\begin{abstract}
This research examines supplier financial risk through the lens of Enactment Theory to explore the role of transparency and communication on buyers' perceptions of supplier default risk. We develop a theoretical model proposing that buyer communication with suppliers leads to preemptive actions that may prevent supplier financial default and fewer supply disruptions. The results suggest that reducing equivocality in buyers through communication with suppliers leads to the understanding of financial factors not captured through third party financial indicators, leading to proactive risk mitigation activities that prevent disruptions during recessionary economic cycles.
\end{abstract}

\section{Purpose:}

This research proposes that transparency and communication reduces equivocality in buyers, spurring them to take contractual actions that reduce financial default in key suppliers, which leads to fewer supply disruptions.

\section{Design/methodology/approach:}

Survey data collected from 175 firms in the North America and Brazil during a period of the global recession is used to test the impact of communication with suppliers on supply chain disruptions in periods of economic crisis. This relationship is mediated by proactive contract renegotiation and supplier financial health, supporting the model grounded in Enactment Theory.

\section{Findings:}

Results show that buyers who regularly assess and develop an understanding of their key suppliers' financial conditions are more likely to re-negotiate contracts that revise payment terms, leading to improved supplier working capital and fewer supply chain disruptions.

\section{Originality/Value:}

The notion of effective communication flows as a means for reduction of supplier disruption risk is aligned with Enactment Theory view that emphasize the benefits of risk reduction. Equivocality is reduced in buyers through information exchange and formal assessments in complex environments. This research suggests that while such communication does not have a direct effect on supply disruption risk, it is mediated through proactive buyer actions to improve supplier financial health and contract re-negotiation mechanisms that may pre-empt financial distress. These are important lessons learned that provide guidelines for supply chain executives in future economic recessions that may occur in the coming years.

Keywords: Supply Disruption Risk, Contract Renegotiation, Buyer-Seller Relationships, Enactment Theory 


\section{An Enactment Theory View of Supplier Financial Disruption Risk Mitigation}

\section{INTRODUCTION}

Supply disruption risk (SDR) refers to the deterioration and/or cessation of supplier performance, influencing enterprise performance across multiple industries, negatively impacting share price, financial returns and operational performance (Blackhurst et al., 2005; Craighead et al., 2007; Hendricks and Singhal, 2003, 2009). SDR has become magnified as more organizations expand their global supply chain networks (Zsidisin \& Wagner, 2010), price and commodity risk (Fischl et al., 2014) and local content requirements drive sourcing from (often financially unstable) local suppliers in emerging markets (Handfield and Krause, 1999). These conditions have escalated enterprise exposure to greater financial risks and probability of supply disruption (Handfield et al., 2013; Jüttner, 2005; Peck, 2005). Global expansion of supplier networks requires real-time monitoring of risk indications (e.g. transparency technologies, block chain) for rapidly changing, continuously expanding, and often unpredictable business conditions (Ellis et al., 2011; Manuj and Sahin, 2011; Handfield and Linton, 2017). Recent studies show that there are significant differences among firms in terms of how information about distressed suppliers are scanned and interpreted, how responses are devised, and how firms learn (Bode and Wagner, 2012).

Supply chain executives recognize supply disruption as a threat to performance (Pournader et al., 2016; Stroud, 2013) but there is a call for research on behavioural perceptions of risk, particularly around learning, scanning, interpretation, and action (Bode and Wagner, 2012). Craighead et al. (2007) present a general framework that synthesizes multiple facets of decision-making involved in managing supply disruption risk. Other research identifies many forms of perceived supply risks including human resource issues, complexity of supply chains, 
strategic alignment of suppliers, performance measures, environment, and financial issues (Christopher et al., 2011; Ellis et al., 2011; Hendricks and Singhal, 2009; Pournader et al., 2016; Shi and Handfield, 2012; Wagner and Johnson, 2004; Zsidisin, 2003; Zsidisin and Wagner, 2010). Of these components, financial default is responsible for about $10-20 \%$ of all supply disruptions (Handfield and McCormack, 2008; Salonen, 2010). During the global economic recession of 2008, many buyers assumed that suppliers were not at risk. During this crisis, many buyers imposed longer payment terms on suppliers despite a shortage of commercial liquidity in the financial sector, forcing suppliers to discontinue operations due to a shortage of working capital (Handfield, 2011). Working capital refers to the ability of an enterprise to meet its shortterm payment obligations to employees and suppliers.

In seeking an explanation for how buyers downplayed the financial risks of their key suppliers during this period, we propose a framework grounded in Enactment Theory to explain how managers behave during a period of economic volatility impacting multiple echelons of industrial supply chains. In a wide-ranging study of supply disruption risk (SDR), Ellis et al. (2011) found that that risk drivers, consequences of risk, risk mitigation tactics and risk assessment metrics comprise important elements in understanding managerial responses to supplier risk. Relying on Ellis et al. (2011) and prior work by Weick (2001) on managerial sensemaking in complex environments, we examine the relationship of buyer behaviour to risk indications in a period of drastic economic contagion.

Our model employs Enactment Theory, and is motivated by Weick (2001) and Ellis et al. (2011), specific to the context of supplier financial distress. Our research contributes to our knowledge of how buyers perceive risk during periods of global economic risk, and suggests that improved perception of risks takes place through open communication, leading to improved 
understanding of supplier financial status and actions to proactively alter contractual terms, which in turn mitigates potential disruptions to supply chain performance. The theoretical model is tested using a sample of North American and Brazilian supply management executives, allowing us to compare respondents from both regions during the global economic crisis of 2008. The unique timing of the sampling frame yields insights on how managers perceive supplier financial risk in periods of economic volatility and contagion. It is motivated by statements such as these: "monitoring and auditing suppliers, may not either provide sufficient information about risks from suppliers, or at least the ability to make appropriate adjustments to avoid disruption occurrence in a timely manner" (Zsidisin and Wagner, 2010, p. 14). Prior research suggests that bounded rationality may restrict a supply management professional's ability to examine the likelihood of supply disruption occurrence stemming from supply-side risk sources (Carter et al., 2007). This post hoc study is due in part to the lag in recognition of the effects of the recession on the global supply chain. (In Brazil, these effects were still being felt in 2017).

The research begins with a discussion of Enactment Theory, the theoretical model, research design, and results, and concludes with a discussion of how buyer perceptions of risk are mitigated through improved communication. We also discuss future research in the behavioural responses of buyers to the threat of financial supplier disruption risk.

\section{LITERATURE REVIEW}

\section{Enactment Theory}

Enactment Theory provides a rich contextual background to frame the discussion of buyer perceptions of supplier disruption risk. Enactment Theory proposes that psychological and social processes determine how individuals and organizations derive meaning, or "make sense" 
from their experiences and indicators (Weick, 1969, 1995, 2001). Sense-making is a "closedloop process comprised of enactment (actions based on previous understanding), selection (interpretation of events) and retention (causal maps) that enable individuals to resolve equivocality" (Ellis et al., 2011, p. 82). Weick (2001) defines equivocality as the extent to which multiple meanings are linked with a situation, whereby those meanings and explanations are subject to infinite revision and ambiguity. In the context of buyers, actions to support suppliers (enactment) is proposed to be a function of information gleaned from discussions with suppliers (selection) and understanding of the depth of their financial problems (retention).

Equivocality arises when multiple derived meanings are attached to perceived indicators of environmental conditions that are subject to revisions as events unfold (Weick, 2001). Enactment Theory applied to SDR by Ellis et al. (2011) suggests that the socio-psychological sense-making processes underlie the formation of buyers' perceptions of supplier risks. Buyers' actions to mitigate supplier risks is a function of how well they comprehend the perils associated with economic contagion in the supply base. Enactment Theory suggests that a buyer's decision to act in the presence of supplier risk is an idiosyncratically satisfying rather than rationally optimizing activity. Moreover, buyers' equivocality reduction processes can be encouraged by promoting accurate views of the environment (communication with suppliers) (Ellis et al., 2011; Zsidisin and Wagner, 2010). This view is embodied in our research model, and further explained in the context of the 2008 global economic crisis.

For managers to make sense out of different signals in equivocal situations requires effective communication and interconnectivity with others in their environment. Intelligence is a process of interconnectivity (Taylor and Van Every, 2000, p. 213), or what Weick describes as "heedful interrelating". A collective mind emerges as a capacity in an on-going activity stream 
when activities among people are tied together as contributions that are subordinated to a joint system (Weick and Roberts, 1993). An inability to make such connections in periods of high uncertainty can be disastrous. Weick (2001) notes that an example of "less heedful interrelating" is Winston Churchill's reconstruction of why he failed to see that Singapore was vulnerable to land invasion in World War II. A good illustration of the awareness of multiple causality may be found in Churchill's response to his horrified discovery that Singapore, rather than being impregnable, provide to be highly vulnerable to a Japanese land invasion (Allinson, 1993). Churchill noted afterwards that "I ought to have known. My advisors ought to have known and I ought to have been told, and I ought to have asked". These four lapses are lapses of interconnection in gathering information about unexpected events (Weick, 2001).

The sense-making context is helpful in explaining why supply managers seemingly faced with the same nominal supply disruption risk (SDR) act in such different manners (in Figure 1a vs. 1b). (These two figures were derived in discussions with executives during the initial stages of survey pre-testing and development, described later). Ellis et al. (2011) propose that equivocality in the face of imminent risk can be reduced through an "internal cognitive constraint" (Barley and Tolbert, 1997). The constraint is comprised of "structures that constrain sense-making by making some actions unimaginable and others self-evident" (Weber and Glynn, 2006, p. 1641). These structures in turn act to shape what people say and do when confronted by supplier risk indicators. But the question remains: what drove some buyers to act when confronted by the 2008 recession risks? What pushed some buyers (but not others) to engage in a dialogue with suppliers, and then commit to help these suppliers with survival strategies to maintain operations through the crisis? 
Prior research suggests that buyers generally have direct communication with supplier sales account managers, and are thus most likely to be able to detect signals of supplier risk that may manifest themselves into supply disruptions (Zsidisin and Wagner, 2010). During the period of the global recession, there were few third party risk assessments tools that assessed the degree of supplier risk (e.g. audits, network analyses, and process analysis), (Bode and Wagner, 2012; Zsidisin and Wagner, 2010) despite a high level of media attention on the crisis. Indeed, interpretation of supplier distress signals has been characterized as a "dynamic hypothesis test in a changing environment" by researchers (Bode and Wagner, 2012, p. 35). A high trust level can increase the clearness of the signals. But actions affect commitment through their effects on beliefs (Salancik, 1977). Commitment in turn can be defined "as a willingness to persist in a course of action" despite the obstacles (Cooper-Hakim and Viswesvaran, 2005, p. 241). As shown in Figure 1b, buyers who communicated with their key suppliers quickly learned they were experiencing financial difficulties. This seems overly simply, yet our research suggests that buyers simply assumed their suppliers would be able to "tough it out" through the difficult economic environment.

What led some buyers to take action while others did not do so during the 2008 period? Research suggests that a variety of factors exist in explaining differences in behavior, including the diversity of structures that constrain sense-making, the level of equivocality inherent in the supply environment, and the organizational and individual factors that affect the equivocality resolution process (Hertzel et al., 2008; Hofler, 2009). This applied cognitive approach to enactment forms the foundation for our study, which sought to provide insights into how buyers reacted differently in pursuing insights into their suppliers' financial condition. 
Research on SDR employs several different theories and constructs across disparate studies, and an emerging body of theory suggests that transparency and communication can reduce equivocality when buyers seek to make sense of signals of supplier risk (Bode and Wagner, 2012; Carter et al., 2007; Zsidisin and Wagner, 2010). An explanatory model was constructed and quantitatively tested to relate the cognitive dissonance on the part of supplier managers during the 2008-2009 global economic crisis, and the reaction of supply managers faced with critical suppliers experiencing the onset of harsh financial distress.

\section{Mitigating Financial Supplier Disruption Risk}

Supplier Disruption Risk (SDR) is defined as the probability of an incident associated with inbound supply from individual supplier failures or the supply market, which results in the inability of the purchasing firm to meet customer demand (Zsidisin, 2003). Research suggests that SDR is a multi-faceted concept, and as such, has significant cognitive and behavioral elements associated with how managers perceive and manage risk (Ellis et al., 2010; Zsidisin, 2003). The psychological and social underpinnings of SDR are in a nascent stage of development (Ellis et al., 2011), and the application of Enactment Theory provides a useful approach for understanding SDR.

Supplier bankruptcy filings are one of the most egregious indicators of supply chain risk. Prior research has found that contagion effects occur prior to suppliers bankruptcy filings, extending beyond industry competitors along the supply chain, as pre-filing distress often results in actions and indicators that have direct consequences for rivals, customers, and suppliers (Hertzel et al., 2008). Using bankruptcy data between 1978 to 2004 from Bankruptcy DataSource Index, financial researchers found that in a sample of 95 Chapter 11 filings, less than $30 \%$ survived (including those who were not merged or acquired) (Hertzel et al., 2008). However, 
historical reviews documenting the 2008-2009 financial crisis, such as "Too Big to Fail" (Sorkin, 2010), suggest that the environment was historically unparalleled in terms of the number of global industries that were impacted by the crisis, with sudden supplier economic contagion across many industries. There was no precedent for the sudden economic contagion that took place during this period, and little research on this subject.

Supplier financial default is one of the prevailing forms of SDR in the global supply chain (Bode and Wagner, 2012; Wagner et al., 2009; Wagner and Johnson, 2004). Financial theory explores financial contagion in terms of investor reaction that learn of a single firm's default, and their resulting awareness of probable contagion of closely associated business partner firms. Investor updates leads to "contagious" jumps in credit spreads of business partners, and can rapidly spread defaults across an entire sector (Giesecke, 2004, 2006).

The common ex-ante strategy for many supplier managers to safeguard against the consequences of a sudden financial default of a supplier is to diversify or install redundancy in the supply base (Anupindi and Akella, 1993; Tang, 2006; Wagner et al., 2009). Other approaches include the integration of contingent sources of supply (Kleindorfer and Saad, 2009; Monczka et al., 2011), inventory buffers (Elmaghraby, 2000), substituting suppliers (Swinney and Netessine, 2009) or risk reduction through alternative contracting mechanisms (Parlar and Perry, 1996). However, all of these actions involve decisions that are post hoc, given conditions of high equivocality of supplier financial risk. These actions are also made more complicated during a period of financial contagion, as risk mitigation cannot be isolated to a single supplier given that default dependencies amongst suppliers are often concurrent in nature (Wagner et al., 2009). During periods of global deleveraging and economic distress, risk mitigation strategies involving redundancy and diversification are ineffective if conditions of default supplier dependencies in 
the portfolio are present (Zsidisin and Wagner, 2010). A wide variety of possible actions may exist depending on whether buying firms are proactive in their interpretation of risk (Bode and Wagner, 2012). High levels of uncertainty, complexity, dynamism and interdependence in the supply base is proposed to escalate equivocality within the SDR decision-making environment (Ellis et al., 2011). Faced with previously unknown indicators in an uncertain environment, “people often don't know what is the 'appropriate action' until they take some action and see what happens" (Weick, 2001, p. 225). In the following section, we introduce hypotheses that underlie our model of supplier risk perceptions and how buyers who acted mitigated their suppliers' financial risk.

\section{HYPOTHESIS DEVELOPMENT}

\section{Financial Supplier Disruption Risk}

We adopt the concepts of Enactment Theory to the case of buyers who failed to recognize imminent disaster in their supply base during the 2008 global economic recession, developed through interviews and embodied in Figure 1a. During the early stages of this recession, the sudden drop in global GDP resulted in cancelled customer orders and Fortune 500 companies faced massive unexpected drops in revenue. Many buyers for these large companies naively assumed that their tier 1 suppliers were not facing the same economic difficulties. Reports show that not only did these buyers discount the risk of suppliers facing the same revenue drops as they cancelled orders to suppliers, but their payment terms on existing orders were lengthened to 90 days or more during this period. (Aeppel, 2008; Milne, 2009). Suppliers to the Fortune 500 companies were unable to find short-term loans to finance on-going operations due to a lack of commercial liquidity across the global financial system. In retrospect, buyers did not recognize the plight of their suppliers, and like Churchill, were not attentive to the systems for gathering 
information on the impact of the recession on suppliers' financial health. In fact, some senior executives at Fortune 500 companies began imposing even longer payment terms beyond 90 days for their weakened supply base (Salonen, 2010). As these smaller suppliers' financial health quickly deteriorated, supply disruptions proliferated, workers were laid off, operations shut down, and existing orders cancelled, followed by bankruptcies (Handfield, 2011; Milne, 2009; Wagner et al., 2009). Many suppliers said nothing until it was too late and banks had shuttered their business, fearful that buyers would cut them off if they knew how bad their situation was. Such relational resistors were in fact driving structural disruptions (Wagner and Fearne, 2015).

A handful of buyers at Fortune 500 companies did NOT react in this manner. As shown in Figure 1b, some buyers recognized the peril that the economic recession might be causing for suppliers, and developed channels of communication to assess the impact on their operations (Handfield, 2011). An important change in Figure 1b is that buyers who effectively approach suppliers in a spirit of transparency are more likely to encourage suppliers to disclose that they are experiencing problems. Prior research suggests that buyers who set the right tone for these communications can build trust leading to more open disclosures on the part of suppliers (Bode and Wagner, 2012; Handfield and Linton, 2017; Handfield et al., 2000; Zsidisin and Wagner, 2010). 


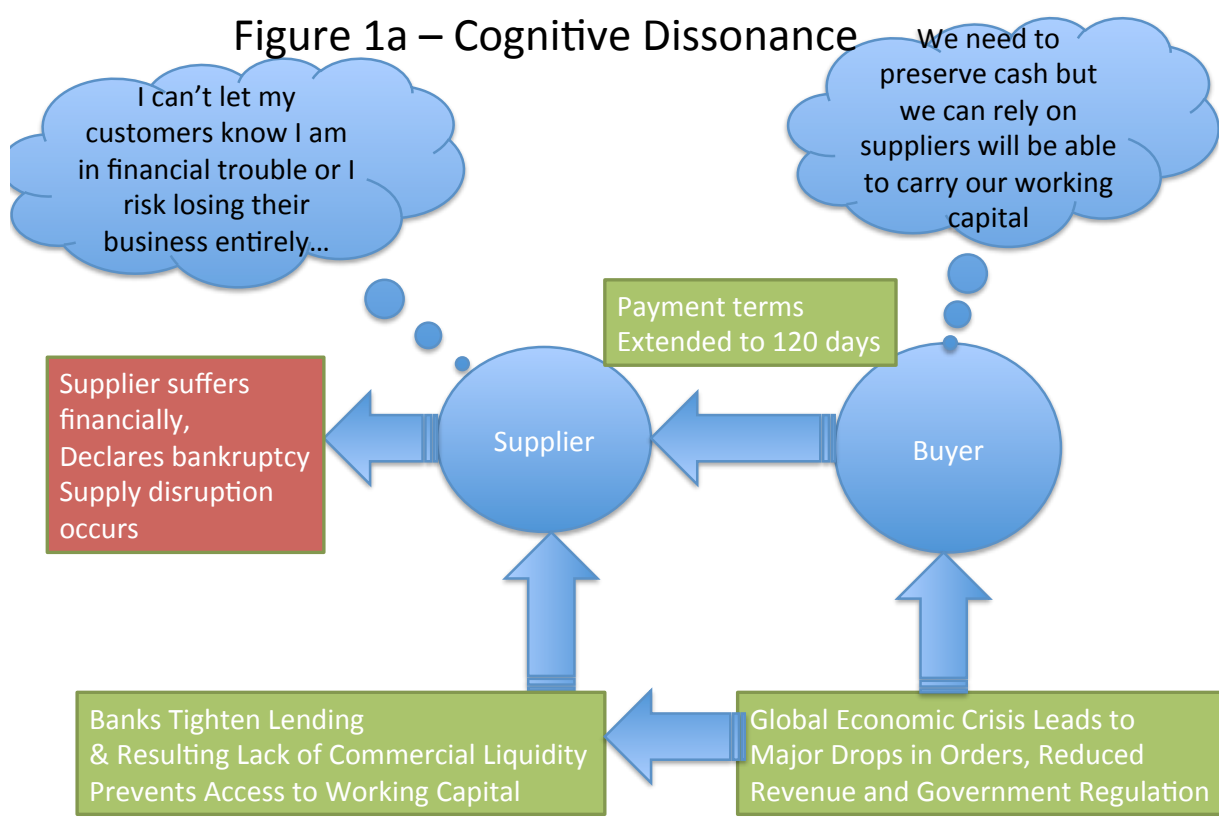

Figure $1 b$ - Open Communication

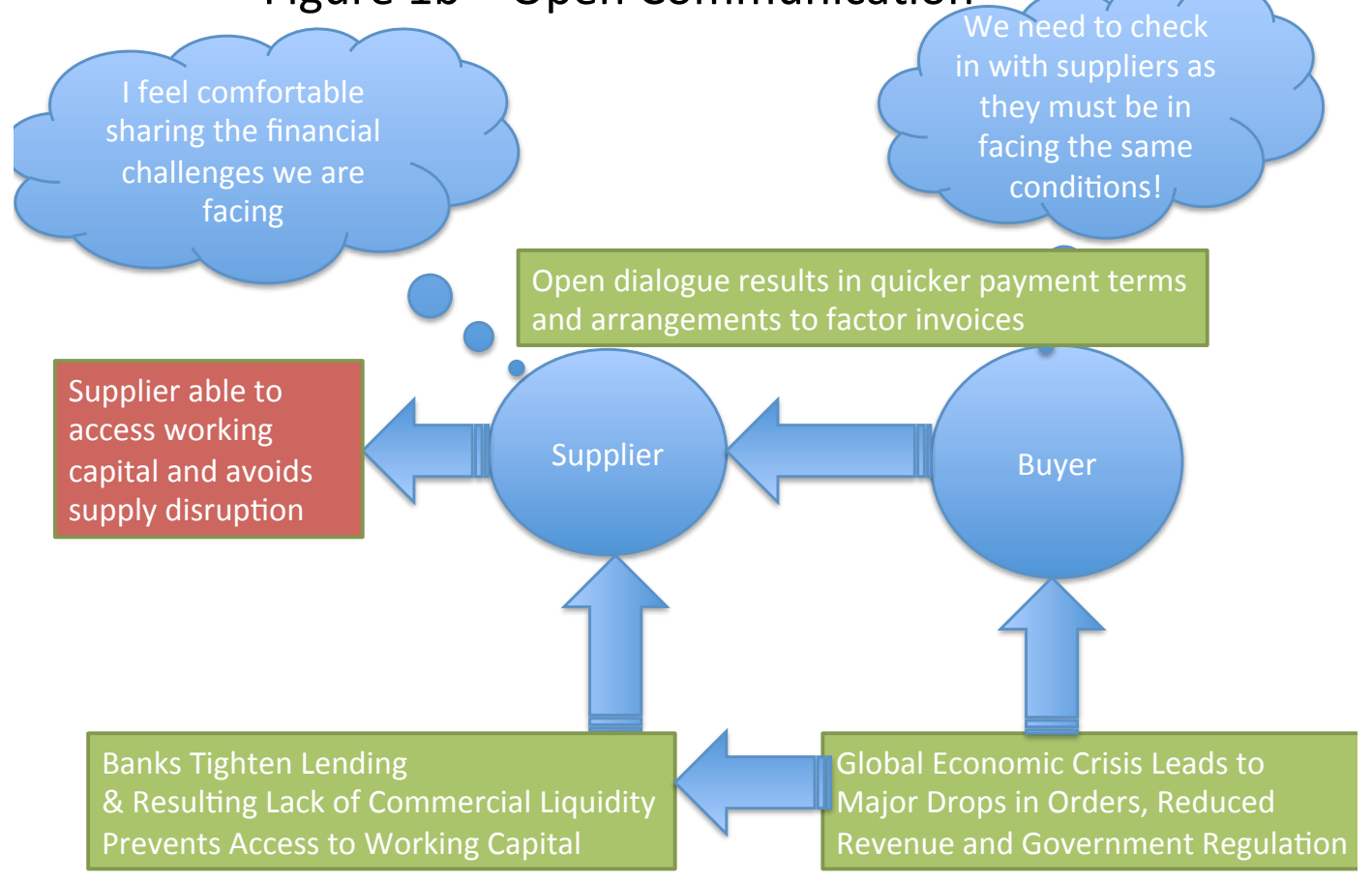

Research suggests that a direct exchange of information between buyers and sellers leads to fewer supply disruptions (Zsidisin and Wagner, 2010). Perceptions of risk indicators are 
"...based on how information on the source of a risk is communicated, the psychological mechanisms for processing uncertainty, and earlier experience of danger. This mental process results in perceived risk: a collection of notions from which people form their own risk sources relative to the information available to them and their basic common sense" (Renn, 2004). Due to the inherent ambiguity and uncertainty of conceptualizing risk, different concepts of risk compete with one other and are based on buyer-specific rationales (Wagner and Fearne, 2015).

Direct buyer communications serves to reduce equivocality regarding a supplier's financial condition, through collection of information that is then translated, interpreted, and acted on (Weick, 2001). Financial models of supply disruption risk state that "the disclosure of information matters a lot: increased transparency reduces the likelihood of contagion effects due to incomplete information" (Giesecke, 2004, p. 1541). We state the relationship as Hypothesis 1 represented in Figure 2:

\section{Hypothesis 1: Increased Buyer-Supplier Communication leads to lower Supply Disruption Risk.}

Prior studies of supplier financial challenges suggest that the primary sources of financial supplier disruption risk were due to lack of working capital brought on by shortages of commercial paper and extension of payment terms (Handfield, 2011; Resende et al., 2009). Working capital refers to the ability of an enterprise to meet its short-term payment obligations to employees and suppliers. In many cases, the root cause of financial distress was not well understood by buyers until an actual conversation had taken place with specific supplier executives. Financial indicators such as D\&B and Moody's were not capturing current conditions, and suppliers were not willing to come forward and openly share their problems with buyers for fear of losing business. Buyers who approached suppliers in a spirit of transparency 
and trust were more likely to hear the full story (Handfield, 2011). A shortage of working capital can quickly shut down operations as a supplier cannot pay employees or buy materials. In such cases, a number of options can solve the problem, including improved payment terms from buyers, factored payments, access to commercial lending, or even short-term loans that prevent supplier operations from shutting down (Bode and Wagner, 2012; Handfield, 2011; Wagner et al., 2009).

\section{Hypothesis 1a: Buyer Awareness of Supplier Financial Health mediates the relationship between increased Communication and lower Supplier Disruption Risk.}

Higher levels of open information exchange between buyers and sellers can shed light not only on a supplier's financial health, but also to issue resolution through collaborative problemsolving (Cousins et al., 2006; Dyer and Nobeoka, 2000). Enactment Theory recognizes the role of the individual's innate preference for social versus independent action, which involves "tolerance, trust, and non-contractual cooperation" (Weick, 2001, p. 213). As a preference for communal behavior increases, individuals become more tolerant and receptive to the reality of a situation, and a preference for a shared understanding follows. In the context of our scenario, buyers who fully grasped the supplier's working capital shortfalls acted immediately to facilitate contract re-negotiations that eased financial distress. Examples of such contractual mechanisms include more favorable terms of payment (30 days or less), discount terms (e.g. 2/10 net 30), reduced inventory holding requirements, shifting of transportation responsibility (FOB Origin vs. FOB Destination), resolving blocked purchase orders, and other factors that impeded the flow of working capital to suppliers. In short, while open communication is important, our model as depicted in Figure 2, proposes that action in the form of renewed contract terms in the face of 
new information is a necessity to de-risk the supply base, modeled here as a mediating activity. This is particularly true give the sudden nature of the global economic recession.

\section{Hypothesis 1b: Proactive Contract Re-negotiation mediates the relationship between Communication and lower Supplier Disruption Risk.}

The idea that default contagion occurs across a network of firms in the same industry is rooted in the financial literature (Giesecke, 2004, 2006), but has a precedent in the automotive and electronic industries. Astute buyers with strong cash flows are in a better position to leverage cash meaningfully to act as a proxy "financial stabilizer" for their suppliers. For instance General Electric and Dell have financed supplier early payments and made this a profitable extension of their core business (Handfield, 2011). Financially stable firms are better equipped to proactively engage with key suppliers to assist with working capital, particularly in periods of economic duress. Larger firms have access to better commercial terms for financing debt relative to suppliers, who are often smaller and subject to higher capital charges (Handfield, 2011; Wagner et al., 2009). Supplier disruptions in turn reduces supply chain flexibility, and a single critical nodal disruption may have ripple effects throughout the supply network (Sheffi and Rice Jr., 2005; Zsidisin, 2003). A bankruptcy or performance disruption at a single supplier is rarely isolated to a singular node, and often impacts multiple suppliers and buyers in the network (Choi et al., 2002; Wagner et al., 2009).

Enactment Theory suggests that buyer's perceptions of a given supplier's financial and performance disruption risk are ideally clarified through open dialogue, leading to validation of perceptions and a more objective reality of the impact on the broader environment (Ellis et al., 2011; Weick, 2001). We propose that buyers in financially stable enterprises who communicate have more resources to assess supplier financial health, which leads to fewer supplier disruptions. As buyers' understanding of how dependent they are on suppliers combined with 
insights into supplier financial challenges, some developed "an innate preference for social versus independent action", which "is about tolerance, trust, and non-contractual cooperation" (Weick, 2001, p. 213). Sense making drove some buyers to become more tolerant and receptive to the notion that suppliers were facing a high risk of bankruptcy, and in some cases led to actions that go beyond traditional contract terms and conditions. For instance, one executive at a large Fortune 500 company noted: "We had to wake up and support our key partners in this environment. We became focused on discussions on how to mitigate risks and make our procurement teams aware of those risks in the current environment" (Handfield, 2011). We thus propose that:

\section{Hypothesis 2 - Financially Stable Buyers Improved Suppliers Financial Health}

As noted earlier, the lens of Enactment Theory suggests that sense-making process led to action in the form of proactive decisions to re-negotiate contract as buyers act through organizational structures, systems and controls that facilitate equivocality reduction, which in turns leads to a richer mental representation of the supply environment (Ellis et al., 2011; Weick, 2001).

The theoretical model embodying these hypotheses is depicted in Figure 2. 


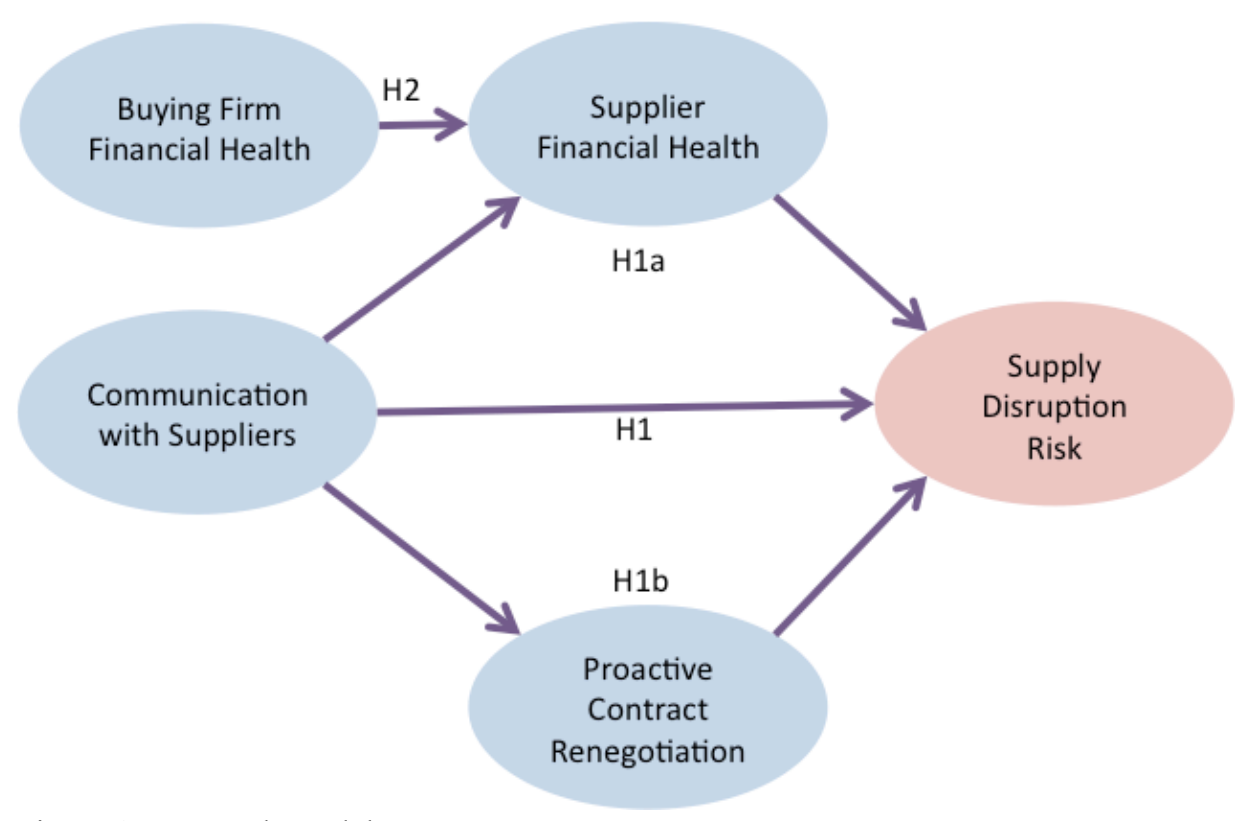

Figure 2: Research model

The research model supports the idea of reciprocal enactment based on perceptions of the supply environment, leading to direct communal action in the form of proactive contract negotiations and reduced supplier financial distress. These antecedents are posited to reduce supplier disruption risks. In the next section, the research method and measurement development are presented.

\section{RESEARCH METHOD AND MEASURE DEVELOPMENT}

The research design sought insights into key issues related to managing supplier financial stress and the impact on subsequent supply disruption risks. Despite established supply management research acknowledging the importance of financial health as a component of supplier evaluation (Monczka et al., 2011), this issue became a disruptive force during the global economic crisis initiated in 2008.

\section{Survey instrument design}


The research model posits that buyer equivocality is influenced through improved communication with suppliers, leading to proactive contract re-negotiation, supplier financial health and reduced supply risk. In this context, the unit of analysis is the supply manager (or "buyer") at firms surveyed in the study, who were asked to share their perceptions of their firm's financial stability, their supplier's financial health, the actions they had taken in response on their part, the communication with suppliers and the resulting level of supply disruption being experienced. A survey of supply managers was deemed as the appropriate vehicle for data collection to test the model. These supply managers were asked to assess the general condition of relationships with "critical" suppliers, as well as the current condition of their financial status. (Note that not all suppliers were deemed to be critical, as non-critical suppliers are often monitored much less)

Multiple discussions with executives in various industries, coupled with secondary research in the press, resulted in the development of a set of questions that focused on the predicted events and responses that organizations might face in the short-term and over the next two years. The survey assessed issues related to financial health of both buyers and suppliers, communication practices with suppliers, contract adaptability and financial supplier disruption risk.

A number of prior works develop various measures for assessing supplier financial risk. However, each of these measures is somewhat unique and does not apply exactly to the specific context identified in this research. For instance, prior measures examine the role of price risk attributable to commodity prices (Fischl et al., 2014), financial health due to pricing pressure (Zsidisin, 2003), or currency exchange risks (Chopra and Sodhi, 2004). None of these measures specifically address the overall financial health of suppliers due to economic contagion across an 
industry, leading to sudden drops in revenue and lack of access to working capital. We therefore derived measures for the buying company's financial health to assess the level of preparedness of the respondent's firm to withstand an economic downturn. For supplier financial health, on the other hand, we measured the buyers' perception of their supplier's financial health in terms of their preparedness to withstand an economic downturn, and whether they were requesting early payments from buyers. The latter factor was identified as a critical indicator of financial problems in suppliers based on interviews we conducted during this period, and differs from prior measures of financial risk. Two items were used, one for large and one for small/medium suppliers, as each of these types of suppliers might face different economic challenges. These metrics are aligned with our thesis regarding Enactment Theory, and whether buyer perceptions of supplier health led to actions and/or subsequent failures or disruptions.

To measure the level of Communication with Suppliers, respondents were asked to rate how frequently companies communicate with their suppliers to update current financial status and also to plan how to possibly they would respond in the event of supply chain's financial disruption. The Proactive Contract Renegotiation construct sought to identify whether the buyer in question was actively re-negotiating contracts with suppliers, by reviewing and strengthening contractual payment terms to drive compliance, share mutual risks and rewards, and modify payment timeframes to help the supplier to avoid cash/flow problems. These actions serve to help establish a commitment to a long-term relationship beyond the immediate economic distressful period.

The endogenous construct of Supply Disruption Risk sought to identify the buyers' risk exposure by accessing whether suppliers are currently experiencing financial problems or are showing signs that their normal operations could be disrupted. Our interviews with buyers 
suggested that the typical signs of distress included difficulty obtaining short-term credit, pricing increases to buyers, erratic deliveries, and putting on hold all future capacity expansion projects.

\section{Pilot testing phase}

The survey was pilot tested in two steps. The draft questionnaire was first sent to six subject matter academics in the area, who were asked to comment on the content, clarity and scaling of the instruments. Several minor changes resulted which involved rephrasing some of the items to clarify their meaning and content. The survey was then submitted to nine industry executives that completed the questions on-line, and who were asked to provide feedback on the content, design and usability of the instrument. Phone interviews were also conducted with these industry experts to ensure their remarks and implications were captured. The industries piloted included life sciences (2), financial services (2), oil and gas (2), automotive (1), and industrial manufacturing (2). A number of design changes were made at this stage to refine the questions and ensure that the wording was consistent with the key themes discussed in the interviews, keeping all questions but reordering and adjusting the survey format to make the data collection instrument more user friendly. Our initial discussions found that some buyers were indeed open to exploring their suppliers' financial status, but others felt that it was not their responsibility, and that it was "every man for himself", consistent with our model development. The survey was translated into Portuguese for the Brazilian firms sample, and back translated to ensure that the English and Portuguese versions were equivalent.

The measures developed for the survey (Shown in Appendix 1) were considered as reflective by representing effects or manifestations of the respective underlying constructs (Hair Jr et al., 2014).

\section{Data collection}


The data were collected through a web-based survey of mid- and upper-level supply managers at North American and Brazilian enterprises. Respondents were asked to answer the survey questions by considering all responses in the context of their own enterprise and key suppliers in the supply base. We also randomly identified a group of 5 respondents from each country who were selected for further interviews to lend insights into the results during this period. Selected extracts from these interviews have been used in the discussion section of the paper to augment explication of the results.

\section{Sample characteristics}

The study was supported by FDC Cabral in Brazil, the Supply Chain Resource Cooperative and the International Association of Commercial and Contract Managers (IACCM) (a global organization). Efforts to enhance the response rate were carried out using two approaches (Forza, 2002). First, a follow up email was sent to the managers within the sample two weeks after the initial mailing. Second, the respondent firms were offered the incentive of a composite summary of the results.

A total of 216 responses were obtained with responses across a wide number of industries. Surveys were conducted via an online survey, and were sent to mailing lists from the Institute for Supply Management, the International Association of Commercial and Contract Management, the Supply Chain Resource Cooperative at NC State University, and executives participating in seminars at FDC University in Brazil. The response rate across these different parties was approximately $21.6 \%$ out of 1000 surveys sent. All responses that had items missing on any of the variables were deleted. This was done to ensure the database consistency, leaving 176 useable responses. Participants included Vice Presidents, Senior Buyers, Managers, and 
Directors. A third were large Fortune 500 companies $(>\$ 5 B)$, the remainder of various sizes. Results were compiled to compare data across these groups, with key themes identified.

After removing one outlier, the final sample of 175 respondents was composed by 106 companies (60.5\%) located in Brazil, $57(32,6 \%)$ in USA and $12(6.9 \%)$ located in Canada. Initially the dataset was examined for equivalence, i.e. if North Americans and Brazilian respondents interpreted and/or responded to questions in the same way, since ignoring equivalence issues can lead to ambiguous or erroneous conclusions (Knoppen et al., 2015). The PLS-MGA test was conducted following the recommendations of Knoppen et al. (2015) in order to test configural, metric and scalar equivalence. PLS-MGA, an extension of the original Henseler's (2009) MGA method, showed no equivalence problems between groups. Configuration equivalence was checked with all indicators loading significantly on the same factors across groups. In the same manner, the metric equivalence test showed no statistical difference on factor loadings across groups with all p-values between the range of $0.05-0.95$ (Sarstedt et al., 2011).

Approximately $25 \%$ of firms had revenue over $\$ 1 \mathrm{~B}, 21 \%$ from $\$ 251 \mathrm{M}-\$ 1 \mathrm{~B}, 19 \%$ $\$ 50 \mathrm{M}-\$ 250 \mathrm{M}$, and $20 \%$ less than $\$ 50 \mathrm{M}$, and were either OEM or tier 1 suppliers to Fortune 500 companies. The remainder did not provide details on sales revenue. Several industries were represented at the sample across industrial, distribution, life sciences, and energy firms, with 144 companies from the consumer goods/products industry.

The response by position was Vice President/Director (14 percent), Senior Manager (57 percent), and Junior Manager (29 percent). By functional area of responsibility, purchasing returned the greatest number of responses (89.9 percent), with the remainder composed of R\&D and manufacturing managers familiar with suppliers. No significant mean differences were 
detected between either of these groups. The average experience in the industry was 9.06 years providing support that research informants were knowledgeable about the issues under investigation.

As this study relied on single respondents and perceptual scales to measure variables, we assessed the presence of common method variance. Common method variance refers to variance caused by measurement methods, threatening the validity of empirical findings and misleading the interpretation of the results (Podsakoff et al., 2003). We performed Harman's single-factor test to check whether common method bias exists. After submitting the raw data to an exploratory factor analysis we inspected the un-rotated factor solutions, and eight factors were identified using Eigen-values with a cut-off point of 1.0, with the first factor explaining 30.6\% of the variance. In addition, the marker-variable test was conducted by taking the smallest correlation among the manifest variables as a proxy for CMV (Malhotra et al., 2006). Comparing the results of the uncorrected estimates with the adjusted estimates the differences were relatively small, leading us to conclude that common method variance was not a significant concern in the sample.

Tests for non-response bias were carried out by comparing early respondents (responses received within the first two weeks) and later respondents (responses received within the third week or later) (Armstrong \& Overton, 1977). A $t$-test of differences was conducted on firm size (employees and sales), and mean responses to each variable. No statistically significant differences were identified.

\section{RESULTS}

To evaluate the reflective measurement models, the internal consistency reliability was initially analyzed by calculating composite reliability as suggested by Hair Jr et al., 2014). The 
composite reliability measures for the measurement models were considered satisfactory with scores ranging from $0.735(\mathrm{SFH})$ to $0.899(\mathrm{BFFH})$.

To establish convergent validity, the average variance extracted (AVE) was computed for each construct of the model showing that constructs were able to explain more than half of the variance of its indicators, (AVE scores were greater than 0.5). All indicators were kept after evaluating the Outer-Loadings and their statistical significance.

Discriminant validity was assessed by examining the cross loadings of indicators (Appendix 1 - Table 3). Results show that all indicators' outer loadings on the associated construct were greater than all loadings on other constructs (i.e., the cross loadings). In addition, the Fornell-Larcker criterion was used to demonstrate that no problems with discriminant validity existed (Table 1), since the square root of the AVE values for the constructs were greater than its highest correlation with any other construct (Hair Jr et al., 2014).

\begin{tabular}{|l|c|l|l|l|l|}
\hline & BFFH & CS & PCR & SDR & SFH \\
\hline BFFH & 0.903 & & & & \\
\hline CS & -0.113 & 0.868 & & & \\
\hline PCR & -0.041 & 0.602 & 0.795 & & \\
\hline SDR & 0.015 & 0.301 & 0.358 & 0.691 & \\
\hline SFH & 0.163 & 0.224 & 0.186 & 0.487 & 0.704 \\
\hline
\end{tabular}

Table 1: Fornell-Larcker Criterion - Correlations table with square root of the AVE in diagonal.

Following this analysis, the structural model was assessed and hypotheses testing conducted using the SmartPLS 3 software (Ringle et al., 2014). PLS-SEM was chosen since it requires no assumptions about the data distribution. Because the questionnaire was based on a 5point scale, detection of normality was not relevant since ordinal scales with few scale points increases skewness and kurtosis (Leung, 2011). PLS-SEM results are considered good proxies 
for CB-SEM (which does require normality) results and, therefore, deemed a good methodological alternative for theory testing when CB-SEM assumptions are violated (Hair Jr et al., 2014).

In order to test the mediation effect of Supplier Financial Health and Proactive Contract Renegotiation, guidelines proposed by Baron and Kenny (1986) were followed. The results of the first analysis (Figure 3a) provided support for Hypothesis 1 by using bootstrapping to test the direct effect between Communication with Suppliers (CS) and SDR without mediator variables. As the bootstrapping procedure performs fairly robustly even when data are non-normal, it should be used as basis for significance testing. In bootstrapping, subsamples are randomly drawn (with replacement) from the original set of data. Each subsample is then used to estimate the model and test the significance of the effects (Hair Jr et al., 2017). Results show that the direct effect of CS on SDR was significant (p-value $<.001$ ) with a path coefficient of $0.317^{1}$.

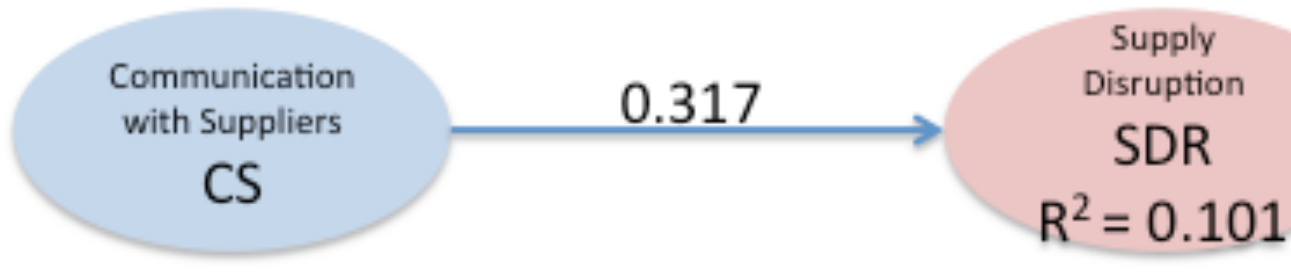

Figure 3a: The direct effect of CS over SDR

The next step taken for the mediation analysis was to test whether the effects of CS over both mediators (Proactive Contract Re-negotiation (PCR) and Supplier Financial Health (SFH)) were significant, and also whether the effects of mediators (PCR and SFH) on Supplier Disruption Risk (SDR) were significant.

\footnotetext{
${ }^{1}$ Higher SDR scores represents lower financial supply disruption risk
} 


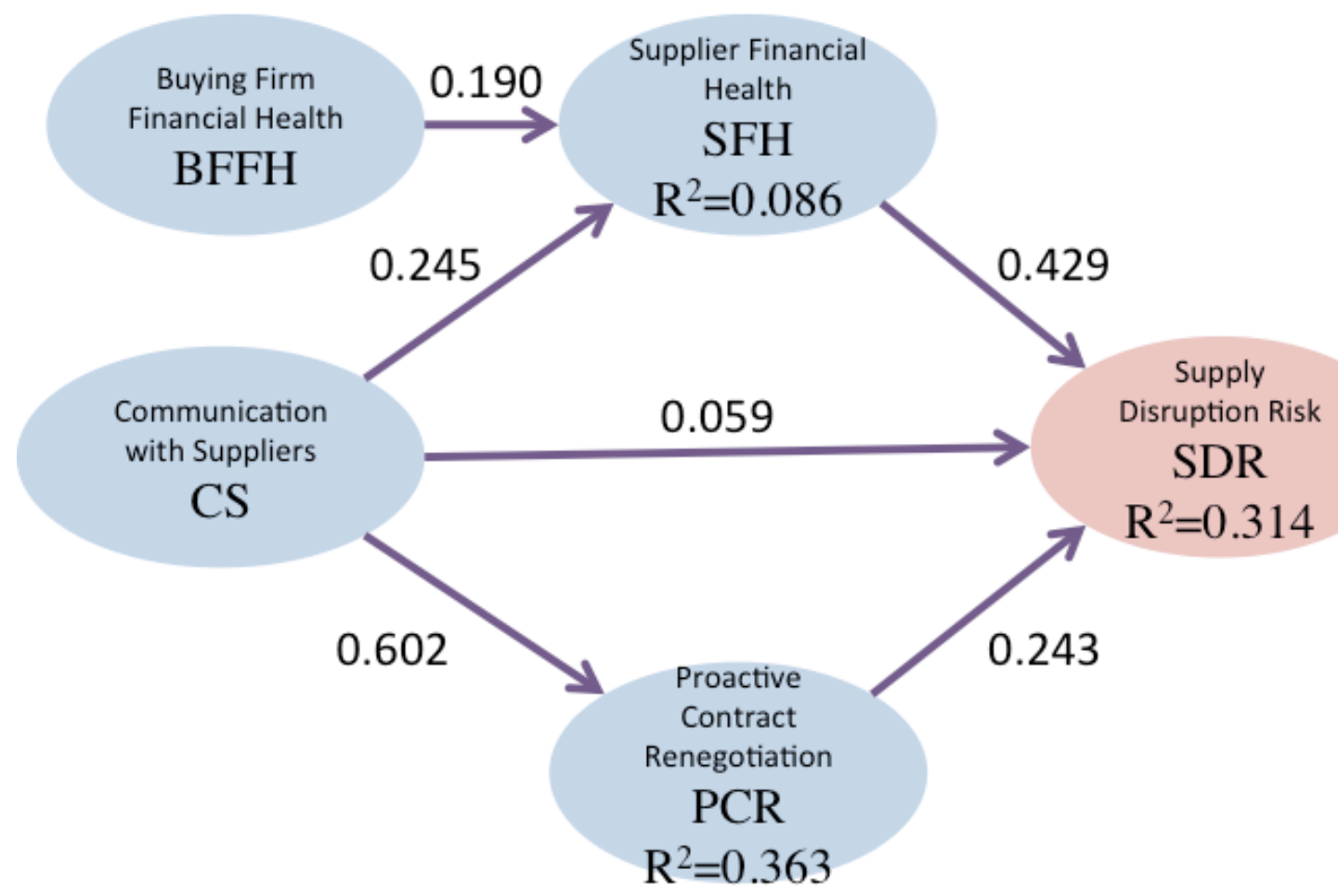

Figure 3b: Path Model (H1a; H1b; H2)

The results shown in Figure $3 \mathrm{~b}$ and Table 2 (below) indicate that all path coefficients were significant with the bootstrapping test (p-values $<0.05)$ after the insertion of both mediators (PCR and SFH), except the direct effect from Communication with Suppliers (CS) to Supply Disruption Risk (SDR). As expected, this factor was rendered insignificant ( $\mathrm{p}$-value $=0.489$ ) after the inclusion of the mediating effects of Supplier Financial Health (SFH) and Proactive Contract Renegotiation (PCR). Also, the path coefficient from Communication with Suppliers (CS) to Supply Disruption Risk (SDR) was reduced from 0.317 to 0.059 , providing further supporting evidence that the effects of the mediators reduced the impact of this relationship. The direct effect of Buying Firm Financial Health (BFFH) over Supplier Financial Health (SFH) was also shown to be significant. 


\begin{tabular}{|l|c|ccc|}
\hline & Path Coef. & $\begin{array}{c}\text { Bootstrapping } \\
\text { Results } \\
\text { (p-values) }\end{array}$ & Hypothesis Number & $\begin{array}{c}\text { Hypothesis } \\
\text { Supported? }\end{array}$ \\
\hline CS -> SDR & 0.059 & 0.489 & H1 - Direct Effect & No \\
\hline BFFH -> SFH & 0.19 & 0.033 & H2 - Direct Effect & Yes \\
\hline CS -> SFH & 0.245 & 0.002 & H1a - Full Mediation & Yes \\
\hline SFH -> SDR & 0.429 & 0 & H1a - Full Mediation & Yes \\
\hline CS -> PCR & 0.602 & 0 & H1b - Full Mediation & Yes \\
\hline PCR -> SDR & 0.243 & 0.003 & H1b - Full Mediation & Yes \\
\hline
\end{tabular}

Table 2: Path coefficients and p-values for the structural model

Finally, it was necessary to evaluate the size of the direct effect from CS to SDR that was absorbed by the mediators. Evaluating the indirect effects presented in this research model, the indirect effect of Proactive Contract Renegotiation (PCR) (0.146) was higher than Supplier Financial Health (SFH) (0.105) and the total indirect effect from Communication with Suppliers (CS) to Supply Disruption Risk (SDR) considering both mediations together was 0.252 with a pvalue $<0.001$. In addition, the Variance Accounted For (VAF) was calculated by taking the total indirect effect divided by the total indirect effect plus the direct effect (VAF = $0.252 /(0.252+0.059)=0.81)$. To summarize, with a VAF of $81 \%$ it was possible to conclude that Supplier Financial Health (SFH) and Proactive Contract Renegotiation (PCR) together are full mediators of Communication with Suppliers (CS) over Supply Disruption Risk (SDR) (Hair Jr et al., 2014).

Finally, in order to verify the behavior of the research model for country effects, we used the Brazilian and North American samples to conduct a multi group analysis test. Results showed no statistical differences of the path coefficients in comparing the model results between the Brazilian and North American samples. Despite minor difference in the average scores of results between the samples, the relationships amongst the constructs of the model were statistically identical when comparing the outcome in each region. 


\section{DISCUSSION AND IMPLICATIONS}

The results of our research have some important implications for the study of buyer-seller relationships and supply disruption risk, as well as identifying other avenues for future research. The results provide strong evidence supporting our model that understanding of supplier's economic conditions can occur through open communication, leading to improved understanding of supplier financial status and actions to proactively alter contractual terms, thereby reducing potential disruptions to supply chain performance. In a broader sense, the model emphasizes the importance of transparency in reducing buyer equivocality on potential risks, and suggests a need for additional research on risks that occur as a result of relational discontinuities between parties (Wagner and Fearne, 2015).

\section{Communication Leads to Proactive Measures}

Supplier managers who establish regular risk-based performance reviews with suppliers are more likely to adjust their payment terms to improve cash flow for suppliers facing problems (Fischl et al., 2014). Examples of communication involve meetings to identify the impact of economic conditions on supplier cash flow, regularly scheduled information sessions to exchange data on a supplier's financial conditions, discussions on contingency planning, and business continuity plans in advance of downward forecasts (Handfield et al., 2000). In addition, research is needed on emerging technologies that provide real-time event notification through on-line procure to pay systems, emerging block chain technologies, and joint platforms for collaboration and sharing information (Handfield and Linton, 2017).

Although over half of the companies in our sample were in communication with suppliers $(60 \%)$ and were discussing business continuity contingency planning $(53 \%)$, less than half were re-negotiating contracts (43\%). Also, over a third of firms had suppliers requesting improved 
payment terms, yet most buyers failed to act on these signals.

Our results support the idea that communication flows can lead to a buyer's improved understanding of their supply network's financial health (H1a), and can also lead to tangible contractual re-negotiation activity (H1b) that can help counter the effects of financial distress and reduce financial supply disruption risk. However, the idea of communication as a direct impact on supplier disruptions was not supported (H1) given the mediating effects of the other two parameters. These results suggest that tangible actions (sense-making followed by enactment) must accompany communication for risk mitigation to be effective. One of the most tangible forms of addressing financial risk is through re-negotiation of contractual terms (Salonen, 2010; Swinney and Netessine, 2009). Our research results suggest that the mediation effect of Proactive Contract Negotiation was stronger than Buyer Financial Health for the relationship between Buyer Communication with Supplier and Supply Disruption Risk. It should be noted that contract re-negotiation may have required buyers to elevate the situation to a higher level, involving financial officers, legal counsel, accounts payable departments, and other functions. The ability to determine the terms for payment to suppliers often goes beyond the buyer in many companies (Monczka et al., 2011), and further research is needed to discuss how cross-functional assessments of supplier financial risk and resulting contract structures should be developed.

A post-hoc analysis was also conducted during this research project, which explored the differences between buying behaviors in the North America and Brazil (The mean difference ttests in responses is shown in Appendix 2).

Comparing the mean values for responses to the questions in the "proactive contracting behavior" construct between the two samples shows that the biggest and most significant difference was related to adopting policy changes to supplier accounts payable terms to 
accommodate cash flow problems (mean difference $=0.735$, p-value $<0.001$ ). On average, results suggest that respondents from North America were more hesitant to accommodate cash flow problems through changes to accounts payable policies for suppliers. The difference in means was also evident when it came to developing informal agreements/MOU's that communicate a long-term agreement (mean difference $=0.581, \mathrm{p}<.01$ ) as well as the willingness to extend contracts for a longer-term relationship (mean difference $=.480, \mathrm{p}<.02$ ) In both cases, North American firms were less willing to make such commitments compared to Brazilian buying firms.

This difference between North American and Brazilian responses to this set of questions may be attributable to several important differences in these cultural settings. Private investors and venture capital typically fund North American companies, while Brazilian companies are strongly dependent on federal funding and a capital structure that was consolidated through several IPO's during the 1998-2008 period. North American enterprises are typically under more short-term financial pressure for investor returns promised to analysts than the counterparts in Brazil, so Brazilian firms may be less likely to extend longer payment terms or reduce commitments to their strategic partners. Future research is required to explore Brazilian vs. North American buying company sentiment (Oliveira et al., 2009), specifically by considering the inter-organizational power structure and strategic interdependence between parties (Mahapatra et al., 2010). A future research topic would explore whether Brazilian executives have a stronger predisposition to engage in contract re-negotiation and commitments to longterm sharing of risks and rewards.

\section{Healthy Buyers Can Make For Healthy Suppliers}

The second hypothesis explored the impact of buyer size on a firm's willingness to 
promote Supplier Financial Health (H2). Approximately two-thirds of the firms in our sample indicated their organization has built up a strong cash position in anticipation of the economic crisis, and over half expressed their belief they were well prepared to manage through the economic trough. Of the firms that were well prepared, larger firms prevailed, although a good mix of small and large companies also expressed the belief that they were in good shape. About $17 \%$ of companies were in a position where cash was so difficult to come by, that they believed they needed to sell a division to build stronger cash position.

Hypothesis 2 suggests that financially healthy firms can leverage their resources effectively to drive actions to improve supplier financial heath during the economic recession. In order to make this real, proactive procurement executives need to be able to express the ROI of investments that reduce SDR. Research is needed to better capture how supplier risk due to working capital exposure and longer payment terms can create financial risk for buyers, and how such risks can be mitigated through alternative payment and financing options for suppliers.

\section{Healthy Suppliers Reduce Disruptions}

Our research results support two other important posited relationships: first, supply chain disruptions may be reduced when buyers focus on improving key supplier's financial health, and second, proactive contract renegotiation practices may also lead to reduction supply chain disruptions. We also note that the direct effect of communication on disruption is not significant; suggesting that communication between buyers and sellers is not a sufficient condition to minimize SDR. When buyers were asked what a probable impact of a supply chain disruption would be, $39 \%$ stated it would reduce revenue, $21 \%$ stated deteriorating customer service, $13 \%$ stated a shutdown of operations and $28 \%$ felt that it would impact two or more of these elements. The total effect of communication on supplier disruption is only meaningful when it occurs 
through its mediator, contract renegotiation (total indirect effect $=0.252$ ). The results support the fact that communication with suppliers must be combined with a proactive approach for meaningful contract renegotiations and access to working capital.

During the global economic recession, only $50 \%$ of buying firms we surveyed were making any efforts to work with and assist suppliers deal with financial issues, and less than $20 \%$ were adjusting policies in accounts payables and receivable. Future research is needed to identify specific cognitive elements that explain financial disruption risk phenomena, especially in the interpretation of different external parameters that drive buyer perceptions regarding the disruption mitigation decision-making process (Ellis et al., 2011). It is especially important to consider multi-tier risk under conditions of contagion, as research suggests that a system-wide characteristic of resilience of the overall supply chain is not necessarily indicative of the resilience of its individual tiers.

\section{LIMITATIONS}

Research of supply chain management, company financial performance (including working capital management), and behavioral sciences through enactment theory are combined to create new information on a complex phenomenon. Even more importantly, the paper supports the axioms of this journal stating that enterprises must move from competing as individual companies, and transform to competing as value chains/business networks. The need for this transformation has been recognized by academia but more empirical studies are needed to link it to industry. However, as in all research, there are limitations with the current study. First, the target sample in this study, in seeing to examine Enactment Theory issues quantitatively, captured perceptions of supplier financial health and buyer financial health using perceptual measures. Validation of industry-specific financial ratios and figures could provide a richer set of 
insights and some quantitative measures for establishing baseline on what levels of financial ratios actually result in disruptions. Future research should also consider using a cross-sectional sample and applying a qualitative approach to capture risk from a greater variety of industries and supply chain dynamics.

Another limitation is that supply disruption data were gathered with a survey instrument deployed at a specific point in time (during a global economic meltdown). Therefore, it is not possible to infer what might happen over a different or extended period of time. This would be an important next step for several reasons. It would be interesting to understand what the outcomes were of these supplies with a longitudinal study revisiting these dyads, and determining what has happened since. Second it will be important to explore the context of communication using real-time information sharing technologies.

\section{CONCLUSION}

The results of this study contributes to our knowledge of how buyers perceive risk during periods of global economic risk, and suggests that improved perception of risks takes place through open communication, improved understanding of supplier financial status, buyer actions to improve contractual terms, and subsequently fewer disruptions to supply chain performance. Open communication is a key component of Supplier Relationship Management, involving postaward contract management with suppliers, which includes the need for on-going monitoring of working capital and financial health conditions.

This research has several implications for supply chain research. First, the results emphasize the importance of regular dialogue and communication with suppliers that may lead to contract re-negotiations. Such efforts may be deemed at first to be counter to contracts, given that there is an impression in many western countries that contracts cannot be modified, and that 
parties are legally bound to contracts under all conditions. The reality of the dire consequences of the global economic recession emphasizes the need for more "relational contracting", as espoused by organizations such as the International Association of Commercial and Contract Management. In such cases, contracts are a vehicle for communication and management of risk, which entail regular communications and discussion. Variation in how such dialogues should take place, their frequency, the types of policies that can be adopted, and the criteria for initiating discussions in various countries may differ, and are a fruitful subject for research in SDR.

A second requirement is the need to extend this research beyond the buyer-supplier dyad. The research suggests that one-on-one discussions can provide insights into financial contagion, but a broader approach to understanding the impact of economic contagion both horizontally (across more than one supplier) and vertically (beyond tier 1 suppliers) can provide additional insights (Bode and Wagner, 2012). A supply chain network approach to risk is consistent with prior research in this journal (Wagner and Fearne, 2015). In addition, the emergence of technologies such as block chain may provide greater transparency on suppliers' financial condition and lead to improved actions on the part of all parties (Handfield and Linton, 2017).

Another important insight is that financial supplier disruption risk has a major impact on operational chain disruption, and that in fact, what happens to suppliers can have a direct impact on buyer's outcomes. This can come in the form of material shortages, price increases, or customer stock-outs, all of which have negative consequences for the buying organization. Our results point to the countervailing forces of contract renegotiation that can help to reduce the likelihood of these events occurring. Such an approach is long overdue as organizations expand their global supply networks to emerging countries and established economic regions alike. 


\section{REFERENCES}

Aeppel, T. (2008), “A Snowblower Maker Braces for Slump's Blizzard of Woe”, The Wall Street Journal, New York, NY, November, available at:

http://online.wsj.com/articles/SB122602502818007621.

Allinson, R.E. (1993), Global Disasters: Inquiries into Management Ethics, Business Ethics Quarterly, Prentice Hall, New York, NY.

Anupindi, R. and Akella, R. (1993), "Diversification Under Supply Uncertainty", Management Science, Vol. 39 No. 8, pp. 944-963.

Barley, S.R. and Tolbert, P.S. (1997), "Institutionalization and Structuration: Studying the Links between Action and Institution”, Organization Studies, Vol. 18 No. 1, pp. 93-117.

Baron, R.M. and Kenny, D. a. (1986), "The moderator-mediator variable distinction in social psychological research: Conceptual, strategic, and statistical considerations.", Journal of Personality and Social Psychology, Vol. 51 No. 6, pp. 1173-1182.

Blackhurst, J., Craighead, C.W., Elkins, D. and Handfield, R.B. (2005), “An empirically derived agenda of critical research issues for managing supply-chain disruptions", International Journal of Production Research, Vol. 43 No. 19, pp. 4067-4081.

Bode, C. and Wagner, S.M. (2012), Financial Distress of Suppliers: Causes, Management, and Consequences, CAPS Research, CAPS Research, Tempe, AZ.

Carter, C.R., Kaufmann, L. and Michel, A. (2007), "Behavioral supply management: a taxonomy of judgment and decision-making biases", International Journal of Physical Distribution \& Logistics Management, Vol. 37 No. 8, pp. 631-669.

Choi, T.Y., Ellram, L. and Koka, B.R. (2002), "Supplier-supplier relationships and their implications for buyer-supplier relationships", IEEE Transactions on Engineering Management, Vol. 49 No. 2, pp. 119-130.

Chopra, S. and Sodhi, M.S. (2004), "Managing Risk To Avoid Supply-Chain Breakdown", MIT Sloan Management Review, Vol. 46 No. 1, pp. 52-61.

Christopher, M., Mena, C., Khan, O. and Yurt, O. (2011), “Approaches to managing global sourcing risk”, Supply Chain Management: An International Journal, Vol. 16 No. 2, pp. $67-81$.

Cooper-Hakim, A. and Viswesvaran, C. (2005), "The Construct of Work Commitment: Testing an Integrative Framework.”, Psychological Bulletin, Vol. 131 No. 2, pp. 241-259.

Cousins, P.D., Handfield, R.B., Lawson, B. and Petersen, K.J. (2006), "Creating supply chain relational capital: The impact of formal and informal socialization processes", Journal of Operations Management, Vol. 24 No. 6, pp. 851-863.

Craighead, C.W., Blackhurst, J., Rungtusanatham, M.J. and Handfield, R.B. (2007), “The Severity of Supply Chain Disruptions: Design Characteristics and Mitigation Capabilities”, Decision Sciences, Vol. 38 No. 1, pp. 131-156.

Dyer, J.H. and Nobeoka, K. (2000), “Creating and managing a high-performance knowledge- 
sharing network: the Toyota case", Strategic Management Journal, Vol. 21 No. 3, pp. 345367.

Ellis, S.C., Henry, R.M. and Shockley, J. (2010), "Buyer perceptions of supply disruption risk: A behavioral view and empirical assessment", Journal of Operations Management, Vol. 28 No. 1, pp. 34-46.

Ellis, S.C., Shockley, J. and Henry, R.M. (2011), "Making Sense of Supply Disruption Risk Research: A Conceptual Framework Grounded in Enactment Theory”, Journal of Supply Chain Management, No. April, pp. 65-96.

Elmaghraby, W.J. (2000), "Supply Contract Competition and Sourcing Policies", Manufacturing \& Service Operations Management, Vol. 2 No. 4, pp. 350-371.

Fischl, M., Scherrer-Rathje, M. and Friedli, T. (2014), "Digging deeper into supply risk: a systematic literature review on price risks", Supply Chain Management: An International Journal, Vol. 19 No. 5/6, pp. 480-503.

Giesecke, K. (2004), “Correlated default with incomplete information”, Journal of Banking \& Finance, Vol. 28 No. 7, pp. 1521-1545.

Giesecke, K. (2006), "Default and information", Journal of Economic Dynamics and Control, Vol. 30 No. 11, pp. 2281-2303.

Hair Jr, J.F., Hult, G.T.M., Ringle, C.M. and Sarstedt, M. (2017), A Primer on Partial Least Squares Structural Equation Modeling (PLS-SEM), 2nd ed., SAGE publications, Los Angeles.

Hair Jr, J.F., Hult, G.T.M., Ringle, C.M., Sarstedt, M. and Hair, J.F. (2014), A Primer on Partial Least Squares Structural Equation Modeling (PLS-SEM), edited by Hair, J.F., Hult, G.T.M., Ringle, C.M. and Sarstedt, M., 1st ed., Sage Publications, Thousand Oaks, California.

Handfield, R. and Linton, T. (2017), The LIVING Supply Chain, John Wiley \& Sons, Inc., Hoboken, NJ, USA, available at:http://doi.org/10.1002/9781119308027.

Handfield, R.B. (2011), "Preparing for the Worst: Sustaining Suppliers Through the Economic Crisis", in Flynn, B., Morita, M. and Machuca, J. (Eds.), Managing Global Supply Chain Relationships: Operations, Strategies and Practices, Busieness Reference, IGI Global, New York, NY, pp. 1-15.

Handfield, R.B. and Krause, D. (1999), “Think globally, source locally”, Supply Chain Management Review, Vol. 3, pp. 36-49.

Handfield, R.B., Krause, D.R., Scannell, T. V. and Monczka, R.M. (2000), "Avoid the Pitfalls in Supplier Development”, Sloan Management Review, Vol. 41 No. 2, pp. 37-49.

Handfield, R.B. and McCormack, K. (2008), Supply Chain Risk Management: Minimizing Disruption in Global Supply Chains, Auerbach Publications.

Handfield, R.B., Straube, F., Pfohl, H.-C. and Wieland, A. (2013), Trends and Strategies in Logistics and Supply Chain Management, BVL International, Bremen, Germany.

Hendricks, K.B. and Singhal, V.R. (2003), "The effect of supply chain glitches on shareholder wealth”, Journal of Operations Management, Vol. 21 No. 5, pp. 501-522. 
Hendricks, K.B. and Singhal, V.R. (2009), “An Empirical Analysis of the Effect of Supply Chain Disruptions on Long-Run Stock Price Performance and Equity Risk of the Firm", Production and Operations Management, Vol. 14 No. 1, pp. 35-52.

Henseler, J., Ringle, C.M. and Sinkovics, R.R. (2009), “The Use Of Partial Least Squares Path Modeling In International Marketing", edited by Henseler, J., Ringle, C.M. and Sinkovics, R.R.Advances in International Marketing, Emerald Group Publishing, Bingley, Vol. 20 No. 2009, pp. 277-319.

Hertzel, M., Li, Z., Officer, M. and Rodgers, K. (2008), "Inter-firm linkages and the wealth effects of financial distress along the supply chain", Journal of Financial Economics, Vol. 87 No. 2, pp. 374-387.

Hofler, D. (2009), "Credit Crisis Collaboration: The Best Cash Flow Alternative", Supply Chain Europe, Vol. 18 No. 2, p. 6.

Jüttner, U. (2005), "Supply chain risk management: Understanding the business requirements from a practitioner perspective", The International Journal of Logistics Management, Vol. 16 No. 1, pp. 120-141.

Kleindorfer, P.R. and Saad, G.H. (2009), "Managing Disruption Risks in Supply Chains", Production and Operations Management, Vol. 14 No. 1, pp. 53-68.

Knoppen, D., Ateş, M.A., Brandon-Jones, A., Luzzini, D., van Raaij, E. and Wynstra, F. (2015), "A comprehensive assessment of measurement equivalence in operations management", International Journal of Production Research, Vol. 53 No. 1, pp. 166-182.

Leung, S.-O. (2011), "A Comparison of Psychometric Properties and Normality in 4-, 5-, 6-, and 11-Point Likert Scales”, Journal of Social Service Research, Vol. 37 No. 4, pp. 412-421.

Mahapatra, S.K., Narasimhan, R. and Barbieri, P. (2010), "Strategic interdependence, governance effectiveness and supplier performance: A dyadic case study investigation and theory development", Journal of Operations Management, Elsevier B.V., Vol. 28 No. 6, pp. $537-552$.

Malhotra, N.K., Kim, S.S. and Patil, A. (2006), "Common Method Variance in IS Research: A Comparison of Alternative Approaches and a Reanalysis of Past Research", Management Science, Vol. 52 No. 12, pp. 1865-1883.

Manuj, I. and Sahin, F. (2011), A Model of Supply Chain and Supply Chain Decision-making Complexity, International Journal of Physical Distribution \& Logistics Management, Vol. 41, available at:http://doi.org/10.1108/09600031111138844.

Milne, R. (2009), "Early warnings in the supply chain”, Financial Times, London, UK, 24 March, available at: http://www.ft.com/cms/s/0/cfaf418e-1813-11de-8c9d0000779fd2ac.html\#axzz3Jdadg0b5.

Monczka, R., Handfield, R., Giunipero, L. and Patterson, J. (2011), Purchasing and Supply Chain Management, 5th editio., Southwestern Publishing, College Division, Cincinnati, $\mathrm{OH}$.

Oliveira, M.P.V. de, Handfield, R., Souza, P.R. de and Resende, P. de T. (2009), "Impactos da crise financeira global nas cadeias de suprimentos: uma comparação entre Brasil x EUA", 


\section{Revista Mundo Logística.}

Parlar, M. and Perry, D. (1996), "Inventory models of future supply uncertainty with single and multiple suppliers”, Naval Research Logistics, Vol. 43 No. 2, pp. 191-210.

Peck, H. (2005), "Drivers of supply chain vulnerability: an integrated framework", International Journal of Physical Distribution \& Logistics Management, Vol. 35 No. 4, pp. 210-232.

Podsakoff, P.M., MacKenzie, S.B., Lee, J.-Y. and Podsakoff, N.P. (2003), “Common method biases in behavioral research: a critical review of the literature and recommended remedies.", The Journal of Applied Psychology, Vol. 88 No. 5, pp. 879-903.

Pournader, M., Rotaru, K., Kach, P.A. and Hajiagha, H.R.S. (2016), “An analytical model for system-wide and tier-specific assessment of resilience to supply chain risks", Supply Chain Management: An International Journal, Vol. 21 No. 5, pp. 589-609.

Renn, O. (2004), "Perception of risks.”, Toxicology Letters, Vol. 149 No. 1-3, pp. 405-13.

Resende, P. de T., Souza, P.R. de, Oliveira, M.P.V. de and Handfield, R. (2009), "Impactos da crise financeira nas cadeias de suprimentos", DOM (Fundação Dom Cabral), Vol. 9, pp. 917.

Ringle, C.M., Wende, S. and Becker, J.-M. (2014), "SmartPLS 3”, SmartPLS, Hamburg, Germany, available at: www.smartpls.com.

Salancik, G.R. (1977), “Commitment and the Control of Organizational Behavior and Belief”, in Staw, M. and Salancik, G.R. (Eds.), New Directions in Organizational Behavior, Robert, Malabar, FL, pp. 1-54.

Salonen, A. (2010), "Reducing supplier risk", Strategic Finance, June, pp. 41-48.

Sarstedt, M., Henseler, J. and Ringle, C.M. (2011), "Multigroup Analysis in Partial Least Squares (PLS) Path Modeling: Alternative Methods and Empirical Results", Measurement and Research Methods in International Marketing, Advances i., pp. 195-218.

Sheffi, Y. and Rice Jr., J.B. (2005), "A Supply Chain View of the Resilient Enterprise", Sloan Management Review, Vol. 47 No. 1, pp. 40-48.

Shi, Y. and Handfield, R. (2012), "Talent management issues for multinational logistics companies in China: observations from the field", International Journal of Logistics Research and Applications, Vol. 15 No. 3, pp. 163-179.

Sorkin, A.R. (2010), Too Big to Fail: The Inside Story of How Wall Street and Washington Fought to Save the FinancialSystem-and Themselves, Penguin.

Stroud, A. (2013), "Managing the Risk of Supply Chain Disruption”, $A P Q C$, available at: http://www.apqc.org/blog/managing-risk-supply-chain-disruption.

Swinney, R. and Netessine, S. (2009), "Long-Term Contracts Under the Threat of Supplier Default", Manufacturing \& Service Operations Management, Vol. 11 No. 1, pp. 109-127.

Tang, C.S. (2006), "Perspectives in supply chain risk management", International Journal of Production Economics, Vol. 103 No. 2, pp. 451-488.

Taylor, J.R. and Van Every, E.J. (2000), The Emergent Organization: Communication as Its Site 
and Surface, Lawrence Erlbaum, Hillsdale, NJ.

Wagner, B. and Fearne, A. (2015), "20 Years of Supply Chain Management: An International Journal", Supply Chain Management: An International Journal, Vol. 20 No. 6, p. SCM-092015-0378.

Wagner, S.M., Bode, C. and Koziol, P. (2009), "Supplier default dependencies: Empirical evidence from the automotive industry", European Journal of Operational Research, Elsevier B.V., Vol. 199 No. 1, pp. 150-161.

Wagner, S.M. and Johnson, J.L. (2004), "Configuring and managing strategic supplier portfolios”, Industrial Marketing Management, Vol. 33 No. 8, pp. 717-730.

Weber, K. and Glynn, M. a. (2006), "Making Sense with Institutions: Context, Thought and Action in Karl Weick's Theory", Organization Studies, Vol. 27 No. 11, pp. 1639-1660.

Weick, K.E. (1969), The Social Psychology of Organizing, Addison-Wesley Publishing Co., Reading, MA.

Weick, K.E. (1995), Sensemaking in Organizations, Sage Publications Inc., Thousand Oaks, CA.

Weick, K.E. (2001), Making Sense of the Organization, Blackwell Publishers Inc., Malden, MA.

Weick, K.E. and Roberts, K.H. (1993), "Collective Mind in Organizations: Heedful Interrelating on Flight Decks", Administrative Science Quarterly, Vol. 38 No. 3, p. 357.

Zsidisin, G.A. (2003), "A grounded definition of supply risk", Journal of Purchasing and Supply Management, Vol. 9 No. 5-6, pp. 217-224.

Zsidisin, G. a. and Wagner, S.M. (2010), "Do Perceptions Become Reality? the Moderating Role of Supply Chain Resiliency on Disruption Occurrence", Journal of Business Logistics, Vol. 31 No. 2, pp. 1-20. 


\section{Appendix 1 - MEASURES}

\section{Please answer all questions as they relate to your key "critical" suppliers of products and services.}

SFH Supplier Financial Health (Composite Reliability 0.735)

- Our large suppliers are well prepared for an economic downturn. (4a - Outer Loading 0.688, p-value $<.001$ )

- Our small to medium sized suppliers are well prepared for an economic downturn. (4b - Outer Loading 0.674, p-value $<.001)$

- We have had suppliers come to us requesting shorter payment terms. ( $4 \mathrm{~d}$ - Outer Loading $0.748, \mathrm{p}$-value $<.001)$

\section{CS Buyer Communication with Suppliers (Composite Reliability 0.860)}

- On going regularly scheduled communication sessions with senior executives of supply chain partners to update current financial status. (7ee - Outer Loading 0.850, p-value $<.001$ )

- Detailed discussions focused on Business Continuity Planning and contingency plans in the event of financial disruptions to supply chain partner operations.

(7gg - Outer Loading 0.886, p-value $<.001)$

\section{BFFH Buying Firm Financial Health (Composite Reliability 0.899)}

- Our organization is well prepared to deal with the current financial crisis. (1a - Outer Loading 0.891, p-value < .029)

- Our enterprise has built a strong cash position in anticipation of an economic crisis. $(1 \mathrm{~b}$ - Outer Loading 0.915 , p-value $<.020)$

\section{PCR Proactive Contract Renegotiation (Actions) (Composite Reliability 0.873)}

- Review and strengthening of contractual terms with key partners to drive compliance. (7aa - Outer Loading 0.871, p-value $<.001$ )

- Review of contracts to discuss re-negotiation of terms that ensure relationship longevity and mutual sharing of risks and rewards.

(7bb - Outer Loading 0.851, p-value $<.001$ )

- Policy changes for supplier/customer accounts payable /accounts receivable terms to accommodate cash flow problems. (7cc - Outer Loading 0.726, p-value $<.001$ )

- Development of informal agreements/MOU's that communicate a commitment to a long-term relationship with key suppliers/customers. (7dd - Outer Loading 0.722, p-value $<.001$ )

\section{SDR Supply Disruption Risk (Composite Reliability 0.783)}

- Suppliers within our supply base have not experienced significant problems in obtaining short-term credit that may risk disruptions to their normal operations.

( $4 \mathrm{e}$ - Outer Loading 0.756 , p-value $<.001$ )

- We have not experienced pricing increases from suppliers associated with the financial crisis. (4f - Outer Loading 0.693, p-value $<.001$ )

- We have not experienced erratic deliveries in the last two months associated with the financial crisis. $(4 \mathrm{~g}$ - Outer Loading $0.670, \mathrm{p}$-value $<.001)$

- We are aware of several suppliers who haven't cut back on future capacity expansion and capital investments for the coming year.

(4h - Outer Loading 0.639, p-value $<.001)$ 


\begin{tabular}{|l|c|c|c|c|c|}
\hline & BFFH & CS & PCR & SDR & SFH \\
\hline $\mathbf{1 a}$ & 0.891 & -0.128 & -0.040 & 0.030 & 0.138 \\
\hline $\mathbf{1 b}$ & 0.915 & -0.078 & -0.035 & -0.001 & 0.155 \\
\hline $\mathbf{4 a}$ & 0.279 & 0.046 & 0.062 & 0.187 & 0.688 \\
\hline $\mathbf{4 b}$ & 0.195 & 0.106 & 0.048 & 0.313 & 0.674 \\
\hline $\mathbf{4 d}$ & -0.036 & 0.261 & 0.235 & 0.458 & 0.748 \\
\hline $\mathbf{4 e}$ & 0.094 & 0.297 & 0.267 & 0.756 & 0.474 \\
\hline $\mathbf{4 f}$ & -0.044 & 0.199 & 0.251 & 0.693 & 0.287 \\
\hline $\mathbf{4 g}$ & -0.023 & 0.194 & 0.238 & 0.670 & 0.248 \\
\hline $\mathbf{4 h}$ & -0.031 & 0.101 & 0.233 & 0.639 & 0.275 \\
\hline $\mathbf{7 a a}$ & -0.107 & 0.560 & 0.871 & 0.317 & 0.199 \\
\hline $\mathbf{7 b b}$ & -0.068 & 0.509 & 0.851 & 0.303 & 0.194 \\
\hline $\mathbf{7 c c}$ & 0.042 & 0.399 & 0.726 & 0.172 & 0.043 \\
\hline $\mathbf{7 d d}$ & 0.036 & 0.426 & 0.722 & 0.326 & 0.124 \\
\hline $\mathbf{7 e e}$ & -0.118 & 0.850 & 0.518 & 0.213 & 0.141 \\
\hline $\mathbf{7 g g}$ & -0.081 & 0.886 & 0.528 & 0.304 & 0.241 \\
\hline
\end{tabular}

Table 3 - Cross Loadings 


\section{Appendix 2 - Differences Between Brazilian and North American Sample Means}

\begin{tabular}{|c|c|c|c|c|c|c|c|c|}
\hline & & \multicolumn{7}{|c|}{ t-test for Equality of Means } \\
\hline & & \multirow[b]{2}{*}{$\mathrm{t}$} & \multirow[b]{2}{*}{ df } & \multirow[b]{2}{*}{ (2-tailed) } & \multirow{2}{*}{$\begin{array}{c}\text { Mean } \\
\text { Difference }\end{array}$} & \multirow{2}{*}{$\begin{array}{l}\text { Std. Error } \\
\text { Difference }\end{array}$} & \multicolumn{2}{|c|}{$\begin{array}{c}95 \% \text { Confidence } \\
\text { Interval of the } \\
\text { Difference }\end{array}$} \\
\hline & & & & & & & Lower & Upper \\
\hline $\begin{array}{l}\text { Existing merger and acquisition } \\
\text { deals have been put on hold until } \\
\text { further notice. (inverse) }\end{array}$ & $\begin{array}{l}\text { Equal variances assumed } \\
\text { Equal variances not } \\
\text { assumed }\end{array}$ & $\begin{array}{l}-2.261 \\
-2.311\end{array}$ & $\begin{array}{r}196 \\
186.667\end{array}$ & $\begin{array}{l}.025 \\
.022\end{array}$ & $\begin{array}{l}-.405 \\
-.405 \\
\end{array}$ & $\begin{array}{l}.179 \\
.175\end{array}$ & $\begin{array}{l}-.758 \\
-.751\end{array}$ & $\begin{array}{l}-.052 \\
-.059\end{array}$ \\
\hline $\begin{array}{l}\text { We are actively encouraging early } \\
\text { retirements in our workforce. } \\
\text { (inverse) }\end{array}$ & $\begin{array}{l}\text { Equal variances assumed } \\
\text { Equal variances not } \\
\text { assumed }\end{array}$ & $\begin{array}{l}2.537 \\
2.461\end{array}$ & $\begin{array}{r}196 \\
154.389\end{array}$ & .015 & .468 & $\begin{array}{l}.184 \\
.190\end{array}$ & $\begin{array}{l}.104 \\
.092\end{array}$ & .843 \\
\hline $\begin{array}{l}\text { We have put on hold all capital } \\
\text { investment activity. (inverse) }\end{array}$ & $\begin{array}{l}\text { Equal variances assumed } \\
\text { Equal variances not } \\
\text { assumed }\end{array}$ & $\begin{array}{l}-2.936 \\
-2.924\end{array}$ & $\begin{array}{r}196 \\
171.867\end{array}$ & $\begin{array}{l}.004 \\
.004\end{array}$ & $\begin{array}{l}-.487 \\
-.487 \\
\end{array}$ & .166 & $\begin{array}{l}-.814 \\
-.815\end{array}$ & $\begin{array}{l}-.160 \\
-.158\end{array}$ \\
\hline $\begin{array}{l}\text { We have held meetings with our } \\
\text { critical suppliers to determine the } \\
\text { impact of the current crisis within } \\
\text { their organization. }\end{array}$ & $\begin{array}{l}\text { Equal variances assumed } \\
\text { Equal variances not } \\
\text { assumed }\end{array}$ & 1.866 & 196 & .064 & .328 & .176 & $\begin{array}{l}-.019 \\
-.011\end{array}$ & .668 \\
\hline $\begin{array}{l}\text { Our large customers are well- } \\
\text { prepared for an economic downturn. }\end{array}$ & $\begin{array}{l}\text { Equal variances assumed } \\
\text { Equal variances not } \\
\text { assumed }\end{array}$ & $\begin{array}{l}-1.690 \\
-1.733\end{array}$ & $\begin{array}{r}196 \\
188.326\end{array}$ & .093 & $\begin{array}{l}-.263 \\
-.263\end{array}$ & .156 & $\begin{array}{l}-.570 \\
-.563\end{array}$ & .036 \\
\hline $\begin{array}{l}\text { Our small to medium sized } \\
\text { customers are well-prepared for an } \\
\text { economic downturn. }\end{array}$ & $\begin{array}{l}\text { Equal variances assumed } \\
\text { Equal variances not } \\
\text { assumed }\end{array}$ & $\begin{array}{l}-2.026 \\
-2.100\end{array}$ & $\begin{array}{r}196 \\
192.395\end{array}$ & .037 & $\begin{array}{l}-.278 \\
-.278\end{array}$ & .137 & $\begin{array}{l}-.549 \\
-.539\end{array}$ & $\begin{array}{l}-.007 \\
-.017\end{array}$ \\
\hline $\begin{array}{l}\text { Customers within have experienced } \\
\text { significant problems in obtaining } \\
\text { short-term credit that may risk } \\
\text { disruptions to their normal } \\
\text { operations. (inv) }\end{array}$ & $\begin{array}{l}\text { Equal variances assumed } \\
\text { Equal variances not } \\
\text { assumed }\end{array}$ & $\begin{array}{l}-3.009 \\
-3.136\end{array}$ & 193.867 & .002 & -.430 & .137 & $\begin{array}{l}-.711 \\
-.700\end{array}$ & $\begin{array}{l}-.148 \\
-.159\end{array}$ \\
\hline $\begin{array}{l}\text { Review and strengthening of } \\
\text { contractual terms with key partners } \\
\text { to drive compliance }\end{array}$ & $\begin{array}{l}\text { Equal variances assumed } \\
\text { Equal variances not } \\
\text { assumed }\end{array}$ & $\begin{array}{l}2.396 \\
2.479\end{array}$ & $\begin{array}{r}196 \\
191.739\end{array}$ & .018 & .420 & .175 & .074 & .766 \\
\hline
\end{tabular}

\begin{tabular}{|c|c|c|c|c|c|c|c|c|}
\hline $\begin{array}{l}\text { Policy changes for } \\
\text { supplier/customer accounts payable } \\
\text { / accounts receivable terms to } \\
\text { accommodate cash flow problems. }\end{array}$ & $\begin{array}{l}\text { Equal variances assumed } \\
\text { Equal variances not } \\
\text { assumed }\end{array}$ & $\begin{array}{l}4.530 \\
4.675\end{array}$ & $\begin{array}{r}196 \\
190.889 \\
\end{array}$ & $\begin{array}{l}.000 \\
.000 \\
\end{array}$ & $\begin{array}{l}.735 \\
.735 \\
\end{array}$ & .162 & .415 & $\begin{array}{l}1.055 \\
1.045\end{array}$ \\
\hline $\begin{array}{l}\text { Development of informal } \\
\text { agreements/MOU's that } \\
\text { communicate a commitment to a } \\
\text { long-term relationship with key } \\
\text { suppliers/customers. }\end{array}$ & $\begin{array}{l}\text { Equal variances assumed } \\
\text { Equal variances not } \\
\text { assumed }\end{array}$ & 3.491 & 196 & .001 & .581 & .166 & .253 & .909 \\
\hline $\begin{array}{l}\text { Morale within our firm is at an all- } \\
\text { time LOW. (inv) }\end{array}$ & $\begin{array}{l}\text { Equal variances assumed } \\
\text { Equal variances not } \\
\text { assumed }\end{array}$ & 2.754 & $\begin{array}{r}196 \\
169.197\end{array}$ & .006 & .480 & .174 & .136 & .824 \\
\hline
\end{tabular}




\begin{tabular}{|c|c|c|c|c|c|c|c|c|}
\hline $\begin{array}{l}\text { We are considering a wave of } \\
\text { downsizing in light of current } \\
\text { economic conditions. (inv) }\end{array}$ & $\begin{array}{l}\text { Equal variances assumed } \\
\text { Equal variances not } \\
\text { assumed }\end{array}$ & $\begin{array}{l}2.511 \\
2.474\end{array}$ & $\begin{array}{r}196 \\
164.932\end{array}$ & $\begin{array}{l}.013 \\
.014\end{array}$ & .459 & $\begin{array}{l}.183 \\
.186\end{array}$ & $\begin{array}{l}.099 \\
.093\end{array}$ & $\begin{array}{l}.820 \\
.826\end{array}$ \\
\hline $\begin{array}{l}\text { We have held a number of town } \\
\text { meetings and discussion groups } \\
\text { with our associates to share our } \\
\text { views on how we plan to handle the } \\
\text { current crisis. }\end{array}$ & $\begin{array}{l}\text { Equal variances assumed } \\
\text { Equal variances not } \\
\text { assumed }\end{array}$ & $\begin{array}{l}2.554 \\
2.576\end{array}$ & $\begin{array}{r}196 \\
179.664\end{array}$ & .011 & .482 & .189 & .110 & .851 \\
\hline $\begin{array}{l}\text { We are actively seeking input from } \\
\text { our associates on opportunities to } \\
\text { improve morale within this } \\
\text { environment. }\end{array}$ & $\begin{array}{l}\text { Equal variances assumed } \\
\text { Equal variances not } \\
\text { assumed }\end{array}$ & 2.083 & 196 & .039 & .369 & .177 & .031 & .706 \\
\hline
\end{tabular}

